\title{
Polyphasic characterization of ITD-01, a cyanobacterium isolated from the Ischia Thermal District (Naples, Italy)
}

\author{
Katia Sciuto, Nicoletta Rascio, Carlo Andreoli \& Isabella Moro* \\ Department of Biology, University of Padova, via U. Bassi 58/B-35131 Padova, Italy \\ "corresponding authore-mail: isabella.moro@unipd.it
}

\begin{abstract}
This paper deals with the characterization of a filamentous cyanobacterial strain, isolated from the microbial mats developing on the thermal muds of Ischia Thermal District (Naples, Italy).

The survey was carried out by a polyphasic approach that includes morphological, ultrastructural, biochemical, and genetic analyses. For the molecular analyses the $16 \mathrm{~S}$ rDNA gene and the $r b c \mathrm{~L}$ gene were considered.

All results showed that this filamentous cyanobacterium belongs to the order Oscillatoriales, family Pseudanabaenaceae. Moreover, the phylogenetic reconstruction suggests that strain ITD-01 might represent the first described entity belonging to a new cyanobacterial genus, whose name might be Protolyngbya.
\end{abstract}

Key words: Protolyngbya, Leptolyngbya, Pseudanabaenaceae, Oscillatoriales, cyanobacteria, thermal spring, polyphasic approach, taxonomy, $16 \mathrm{~S} \mathrm{rDNA}, r b c \mathrm{~L}$

\section{Introduction}

The thermal waters of Ischia Island (Naples, Italy) have been famous and used for their therapeutic properties since ancient times, in particular by Greeks and Romans, as attested by numerous archaeological findings. From the $17^{\text {th }}$ to the middle of the $20^{\text {th }}$ century, near the most famous thermal springs, numerous establishments were built, which nowadays persist constituting the Ischia Thermal District and being exploited by thousands of people for therapeutic purposes every year. In spite of this, information on the Ischia Thermal District are limited to few Italian publications, in particular regarding the history and geology of the island, a summary of which can be found at the sites http://www.terme.ischia.it/uk/ and http:// www.ischiaonline.it/. About the biodiversity of this environment, at our knowledge there is only one study by Pitschmann dating back to 1969 .

Because of the different chemical composition of the grounds encountered during their way towards the surface, Ischia thermo-mineral waters can be distinct in bicarbonate-calcic waters, bicarbonatealkaline waters, transition waters, and sulphatechloride-alkaline waters (Fig. 1). Moreover the water temperature of the different establishments varies considerably, ranging from $15{ }^{\circ} \mathrm{C}$ to $86^{\circ} \mathrm{C}$.
For these reasons various organisms can be found in the different Ischia sites, including bacteria, protozoa, microalgae, and cyanobacteria.

Cyanobacteria (phylum Cyanophyta) are a group of photosynthetic prokaryotes with both coccoid and filamentous forms. These microrganisms are able to live in a wide range of environments, including those considered extreme, such as deserts, alkaline waters, ipersaline pounds, glaciers, and hot springs (WARD et al. 1998; PAERL et al. 2000; LóPEZ-CorTés et al. 2001; JunGBLUt et al. 2005; SÁNCHEZ-BARACALDO et al. 2005; TATON et al. 2006a).

Cyanobacteria are known for their ability to produce several bioactive compounds that can be exploited for different applications, among which medical therapies (SINGH et al. 2005; ERIKSEN 2008; Gerwick et al. 2008; Sivonen \& Börner 2008).

In particular, surveys carried out on Phormidium sp. ETS-05, a cyanobacterium isolated from the Euganean thermal District (Padova, Italy), another Italian thermal environment, have shown how this microrganism greatly contributes to the anti-inflammatory properties of the mud, thus representing an integral part of mud therapies (LALLi et al. 2004; BRUNO et al. 2005; Marcolongo et al. 2006). Phormidium 
sp. ETS-05 belongs to the order Oscillatoriales, a group whose members are able to produce nearly half of the bioactive cyanobacterial compounds noticed so far (GERWICK et al. 2008).

In this study we characterize a cyanobacterium isolated from mats growing on the thermal mud surface of Ischia Thermal District. The organism, referred in the text as strain ITD-01 (where 'ITD' stands for 'Ischia Thermal District'), has been characterized using a polyphasic approach, that includes morphological, ultrastructural, biochemical, and molecular analyses. For the molecular analyses the $16 \mathrm{~S}$ rDNA gene, classically used as a molecular marker for cyanobacteria (IsHIDA et al. 1997; WARD et al. 1998; Casamatta et al. 2005; Palinska \& Marquardt 2008; WACKLIN et al. 2009), and the $r b c \mathrm{~L}$ gene, only recently used (TOMITANI et al. 2006, Moro et al. 2010), were considered. Currently, indeed, the polyphasic approach seems a must in order to correctly identify new strains belonging to the phylum Cyanophyta, as underlined by several authors (ABED et al. 2002; KomÁREK 2005; TATON et al. 2006b; Moro et al. 2010).

This survey would represent the first of a series concerning the cyanobacterial biodiversity of Ischia thermal District, with the aim to draw a parallel to the Euganean thermal environment and also in order to better understand the potential contribution of Ischia cyanobacteria to mud therapies.

\section{Material and methods}

Blue-green mats developing at the surface of sedimentary thermal muds of NH Ischia Thermal Spa Resort (Naples, Italy) (40 $44^{\prime} 0^{\prime \prime}$ North, $13^{\circ} 36^{\prime} 0^{\prime \prime}$ East) (Fig. 1) were collected in April 2009. The temperature of the water in the tanks was about $30^{\circ} \mathrm{C}$ with a $\mathrm{pH}$ of 7. Axenic cultures were cultured in BG11 medium (RIPPKA et al. 1979) in a growth chamber at $30{ }^{\circ} \mathrm{C}$, with a light intensity of $35 \mu \mathrm{mol}$ photons $\mathrm{m}^{-2} \mathrm{~s}^{-1}$ and a dark:light cycle of 12:12 hours.

All morphological observations and biochemical analyses were carried out on cultures in exponential growth phase.

A living culture of the Ischia strain has been deposited at the Culture Collection of Autotrophic Organisms (CCALA) (Czech Republic) with the strain number 945.

Observations of cultured cells were made with a DMR Leica (Sweden) microscope equipped with a digital image acquisition system. The morphological identification of the strain was based on the diacritic

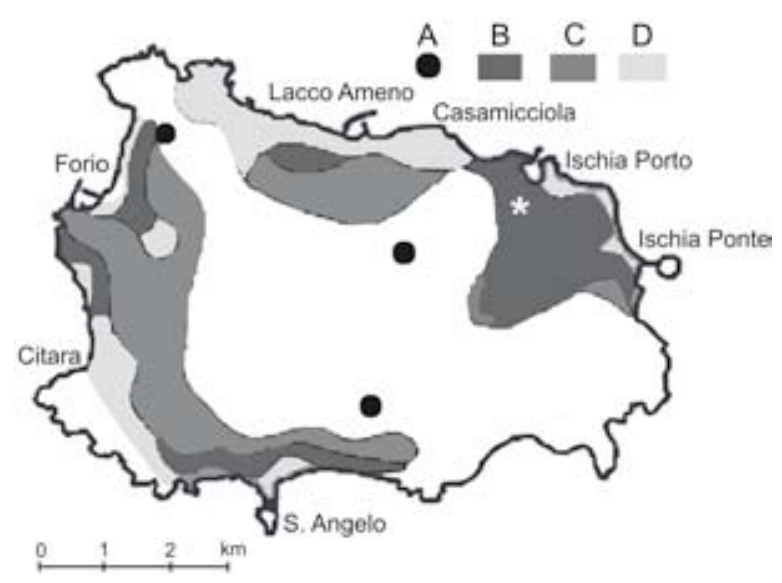

Fig. 1. Map of the Ischia Island showing the hydrogeochemical facies present in the island: (A) bicarbonate-calcic waters; (B) bicarbonate-alkaline waters; (C) transition waters; (D) sulphate-chloride-alkaline waters. The white asterisk indicates the sampling site.

traits proposed by KomÁReK \& ANAgnostidis (2005).

For scanning electron microscopy (SEM) cultured cells were fixed in $3 \%$ glutaraldehyde in $0.1 \mathrm{M}$ cacodylate buffer ( $\mathrm{pH}$ 6.9) for four hours at $4{ }^{\circ} \mathrm{C}$ and further treated according to Moro et al. (2007). For transmission electron microscopy (TEM), cells were fixed in 3\% glutaraldehyde in $0.1 \mathrm{M}$ cacodylate buffer ( $\mathrm{pH}$ 6.9) for four hours at $4{ }^{\circ} \mathrm{C}$. After being washed in cacodylate buffer, the specimens were post-fixed in $1 \% \mathrm{OsO}_{4}$ in the same buffer for two hours and dehydrated in a graded ethanol series followed by propylene oxide. The specimens were stained with uranyl acetate while undergoing dehydration in $75 \%$ ethanol. The samples were embedded in Araldite resin. Ultrathin sections were cut with an Ultracut S, Reichert ultramicrotome (New York, USA), post-stained with lead citrate, and examined with a HS9 Hitachi (Tokyo, Japan) transmission electron microscope operating at $75 \mathrm{kV}$. Phycobiliproteins (PBPs) were extracted from pellets of cultured cells finely ground in a mortar with liquid nitrogen according to Moro et al. (2007). The extract absorbance was measured with a DU530 Beckman Coulter spectrophotometer(Fullerton, California, USA) at $562 \mathrm{~nm}$ (phycoerithrin), $615 \mathrm{~nm}$ (C-phycocyanin) and $652 \mathrm{~nm}$ (allophycocyanin), and PBPs concentrations were calculated using the extinction coefficients proposed by BenNeTT \& BOGORAD (1973).

The chlorophyll $a$ and carotenoid analyses were carried out by reversed phase high performance liquid chromatograph (HPLC) on cultured cell extracts according to KomÁreK et al. (1999) and Moro et al. (2010).

Genomic DNA was extracted from cell pellets, using the Genomic DNA purification kit (Fermentas ${ }^{\odot}$, Burlington Ontario, Canada). The 16S rDNA gene was amplified from DNA extracts by PCR, using the primers and the conditions reported in MORO et 
al. (2007). The amplification of the $r b c \mathrm{~L}$ gene was carried out with the primers reported in TOMITANI et al. (2006). The PCR products were visualized with ethidium bromide staining after electrophoresis in a $1 \%$ agarose gel, purified with the ExoSAP-IT ${ }^{\mathrm{TM}}$ kit (Amersham Biosciences, Piscataway, New York, USA) and directly sequenced. The sequencing was performed at the BMR-Genomics Sequencing Service (University of Padova) on automated DNA sequencers on both strands to ensure accuracy of the results. The final consensus sequences were assembled using the SeqMan II program from the Lasergene software package (DNAStar ${ }^{\circ}$, Madison, WI) and analyzed by similarity search using the BLAST program (ALTSCHUL et al. 1990), available at the NCBI web server (www. ncbi.nlm.nih.gov/blast) and the ARB database (LUDWIG et al. 2004). After the similarity search, the most similar sequences were selected.

For each molecular marker a distinct dataset was created including, besides Ischia strain ITD-01, other isolates identified and described as members of the family Pseudanabenaceae. A group of sequences from heterocystic cyanobacteria was used as outgroup.

The sequences were aligned for phylogenetic analyses using the ClustalW computer program (THOMPSON et al. 1994) and nucleotide positions containing gaps or missing data were deleted.

To infer phylogenetic relationships among the taxa maximum parsimony (MP) method, using the $M E G A$ version 4.0 software (TAMURA et al. 2007), and maximum likelihood (ML) method, with the PHYML 2.4.4 program (GUINDON \& GASCUEL 2003) by applying the GTR $+\mathrm{I}+\mathrm{G}$ evolutionary model (LANAve et al. 1984), were performed. Non parametric bootstrap resampling (FELSENSTEIN 2003) was carried out to test the robustness of the tree topologies (1000 replicates).

Bayesian Inference method was applied too, using MrBayes version 3.1 (Ronquist \& HuelsenBeck 2003). The substitution model was the $\mathrm{GTR}+\mathrm{I}+\mathrm{G}$, also in this case. The Bayesian analyses were performed with four search chains for 1,100,000 generations for the $16 \mathrm{~S}$ rDNA gene and 1,000,000 generations for the $r b c \mathrm{~L}$ gene, sampling trees every 100 generations. The first 2,500 trees were discarded as burn-in. Parameter stability was estimated by plotting log-likelihood values against generation time, and a consensus tree with posterior probabilities was produced. The nexus files for the Bayesian analyses were generated with the Mesquite 2.71 software package (MADDISON \& MadDison 2009).

The phylogenetic trees were visualized through NJplot (Perriére \& Gouy 1996). The 16S rDNA and $r b c \mathrm{~L}$ gene sequences of Ischia strain ITD-01 were deposited in DDBJ/GenBank ${ }^{\mathrm{TM}} / \mathrm{EBI}$ Data Bank with the accession numbers FR716825 and FR716826 respectively.

\section{Results and discussion}

Ischia strain ITD-01 showed bright blue-green, long, very thin, not-branched filaments (Fig. 2). Moreover, the filaments were isopolar, densely packed and entangled, forming expanded bluegreen mats on the substrate. Each trichome was composed by longer than wide cells, ranging from 0.8 to $1.5 \mu \mathrm{m}$ in length and 0.7 to $0.9 \mu \mathrm{m}$ in width and showed distinct constrictions at the cross walls (Fig. 3). Trichomes were surrounded by a colourless sheath and showed rounded apical cells (Fig. 4). Cell division took place perpendicularly to the longitudinal axis of the trichome. The daughter cells divided and grew to the size of the mother cell before the next division. Reproduction was by trichome fragmentation in short hormogonia without necridium formation (not shown). No heterocysts were observed.

Transmission electron microscope observations confirmed the presence of a sheath (about $0.15 \mu \mathrm{m}$ thick) surrounding the trichomes and the presence of 3-4 thylakoids arranged in parallel at the periphery of the cells (Fig. 4). In the cytoplasm of most cells some inclusions were present. No gas vesicles were observed.

The morphological and ultrastructural features observed in the Ischia strain ITD-01, in particular the not-branched filaments without heterocysts, place it into the order Oscillatoriales (KomÁreK \& ANAGNOSTIDIS 2005). In addition, the peripheral thylakoids arrangement (KOMÁREK \& ČÁsLAVSKÁ 1991) and the type of cell division are typical of the family Pseudanabaenaceae (KomÁreK \& ANAGNostidis 2005). More in depth, the isopolar trichomes surrounded individually by a sheath lead us to ascribe our strain to the sub-family Leptolyngbyoideae, while the packed and entangled aspect of the filaments, which form expanded blue-green mats on the substrate, is a feature common to the genus Leptolyngbya. Finally, the trichome cells, longer than wide, and the reproduction by trichome fragmentation without necridia suggest that strain ITD-01 can be ascribe to the subgenus Protolyngbya. In fact, in order to facilitate the identification of cyanobacterial strains belonging to this taxon, the current genus Leptolyngbya has been divided in two subgenera: Leptolyngbya and Protolyngbya, which differ mainly for the cell morphology and for the presence/absence of necridic cells (KOMÁREK \& ANAGNOSTIDIS 2005; KoMÁreK 2007).

The genus Leptolyngbya is, indeed, one 

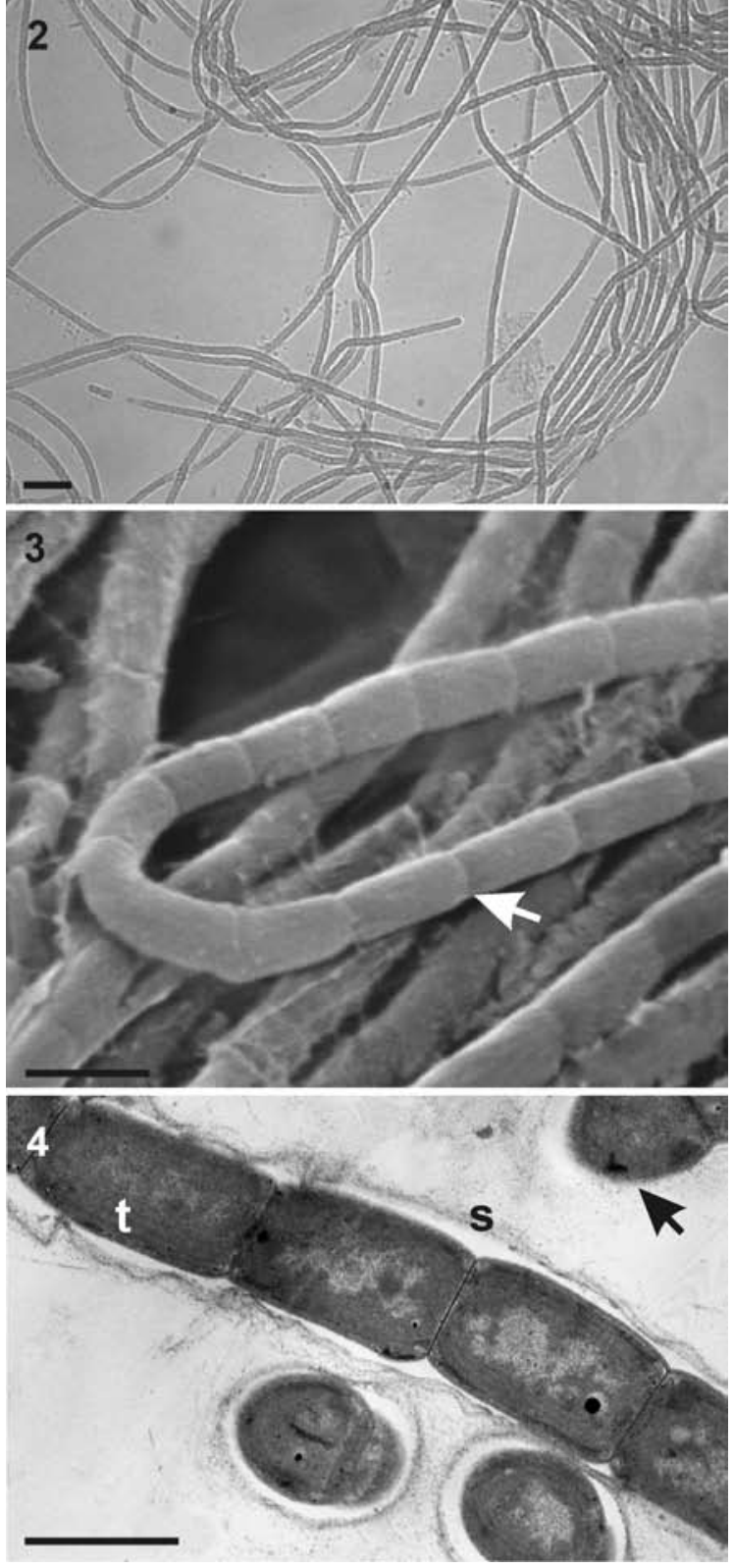

Figs 2-4. Ischia strain ITD-01: (2) light micrograph showing long, very thin, not-branched trichomes. Bar $=5 \mu \mathrm{m}$; (3) scanning electron micrograph of trichomes characterized by cylindrical cells and by distinct constrictions at the cross walls (arrow). Bar $=1 \mu \mathrm{m}$; (4) transmission electron micrograph showing a trichome characterized by cells with parallel thylakoids (t), arranged at the periphery of the cells, and surrounded by a sheath (s). A rounded apical cell can be seen (arrow). Scale bar $1 \mu \mathrm{m}$.

of the most systematically complex group of the phylum Cyanophyta. In fact, because of the simple morphology and very small dimensions of its members, the intrageneric taxonomic classification of this genus results quite difficult (KomÁreK \& ANAGNostidis 2005; KomÁreK 2007) and its heterogeneity has been highlighted by more and more authors, who advocate the separation of this taxon into distinct subgroups, according to molecular as well as ultrastructural and ecophysiological criteria (AlBertano \& KováčiK 1994; TAton et al. 2003; CAsamatta et al. 2005; KOMÁreK 2007; Bruno et al. 2009; Moro et al. 2010).

The spectrophotometric measurements of buffered saline PBP extracts of Ischia strain ITD01 showed the presence of C-phycocyanin (68\%), allophycocyanin (28\%), and phycoerythrin (4\%). The high amount of C-phycocyanin (68\%), known for its various medicinal as well as pharmacological properties (RomAY et al. 1998; VAdiraja et al. 1998; Вhat \& Madyastha 2001), suggests the possible contribution of this strain to the therapeutical properties of the mud. Of course, this hypothesis should be tested in the future, as it has been done for the Euganean cyanobacterial strain ETS-05 (LALLi et al. 2004; BRUNO et al. 2005; MARCOLONGO et al. 2006).

The HPLC analyses evidenced lipid-soluble pigment pattern corresponding to myxol-2'glycoside, nostoxanthin, caloxanthin, zeaxanthin, chlorophyll $a$, trans $-\beta$ carotene, and cis $-\beta$ carotene. Some of them, such as myxol-2-'glycosides, are characteristic carotenoids in cyanobacteria (TAKAIChI \& Mochimaru 2007). The absence of echinenone, a pigment commonly present in cyanobacteria, has been already observed in other filamentous cyanobacterial strains, such as those belonging to the genus Halomicronema (ABED et al. 2002).

The 16S rDNA and the $r b c \mathrm{~L}$ gene datasets for ML phylogenetic analyses were constructed with the nucleotide sequences obtained in this study plus other sequences available in the DDBJ/GenBank ${ }^{\mathrm{TM}} / \mathrm{EBI}$ Data Bank for other cyanobacterial strains assigned to the Oscillatoriales, focusing in particular on those belonging to the Pseudanabaenaceae family, to which strain ITD-01 could be assigned according to the morphological and ultrastructural observations. Unfortunately, for the $r b c \mathrm{~L}$ gene a limited number of sequences were available in the public databases.

The phylogenetic analyses carried out according to the different methods gave similar results, except for the positions of some internal nodes. Anyway, as same clades were detected with all the methods, we depicted only the ML topologies, reporting the MP and ML bootstrap values and the posterior probabilities at the congruent nodes. 


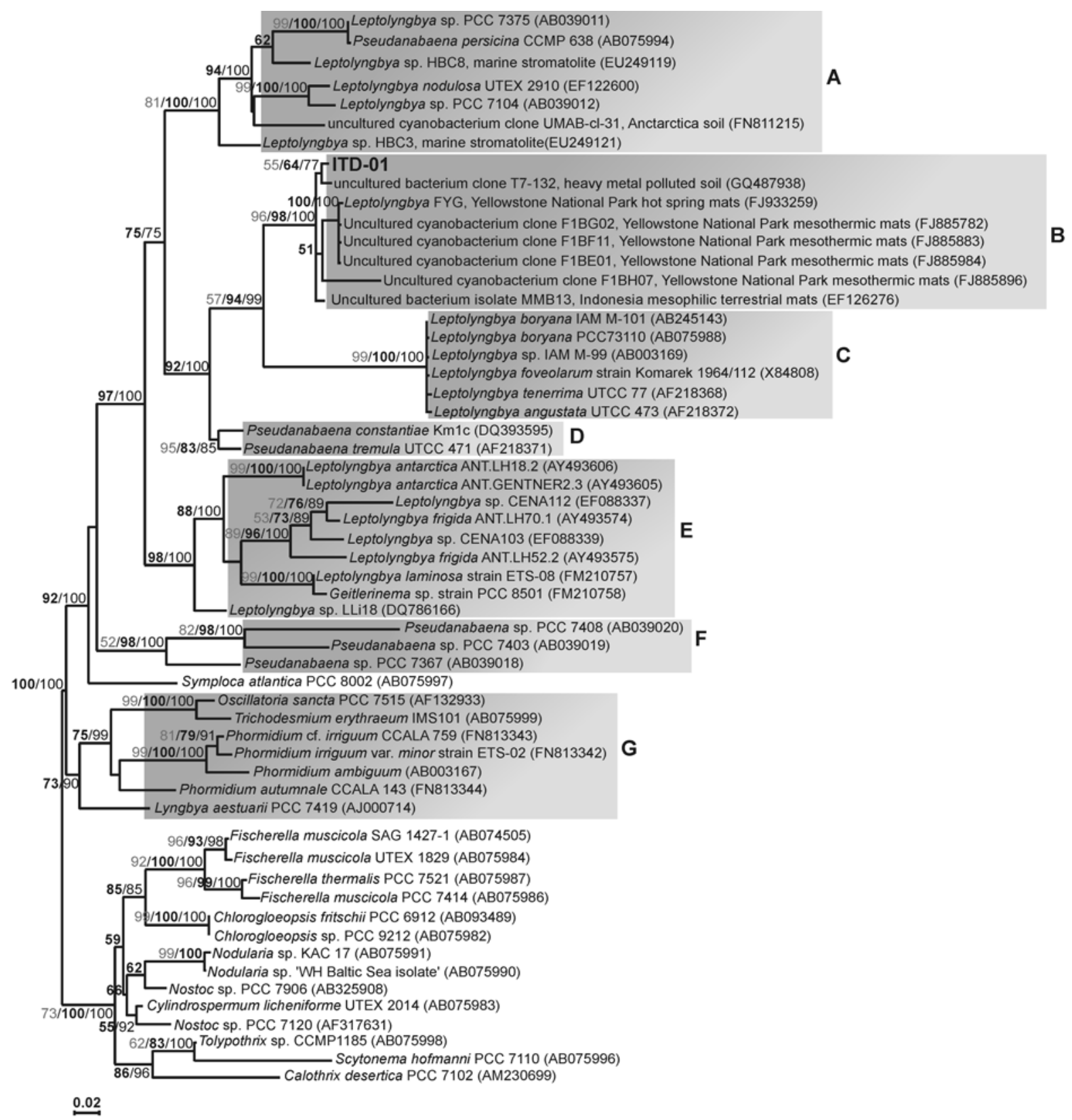

Fig. 5. Phylogenetic tree based on the 16S rDNA gene sequences and reconstructed using the maximum-likelihood analysis. MP and ML bootstrap values ( $\geq 50 \%$ ) and Bayesian posterior probabilities are provided for each node (MP in grey, ML in bold, and $\mathrm{BI}$ in normal font). GenBank accession numbers are indicated in brackets. Bar represents 0.02 nucleotide substitutions per site.

In the phylogenetic reconstruction based on the $16 \mathrm{~S}$ rDNA gene different clades could be distinguished (Fig. 5). Strain ITD-01 grouped in clade B with several organisms named as 'uncultured bacterium' or 'uncultured cyanobacterium' and with a strain ascribed to the genus Leptolynbgya under the name Leptolyngbya sp. strain FYG, through a node supported by a MP bootstrap value of $96 \%$, a ML bootstrap value of $98 \%$, and a posterior probability of $100 \%(96 / 98 / 100 \% \mathrm{BT} /$ $\mathrm{BT} / \mathrm{PP})$. We are aware that the use of sequences belonging to non-identified and/or uncultured organisms in phylogenetic analyses is an incorrect practice, that can create confusion, but in this case we thought that could be worth to include this sort of sequences, which were found by BLAST as the most similar to our one. The majority of them, in fact, belong to microrganisms living in other famous thermal springs, the Yellowstone National Park (U.S.A.) hot springs.

With a 57/94/99\% BT/BT/PP of support clade $\mathrm{B}$ resulted sister taxon to clade $\mathrm{C}$. This last 


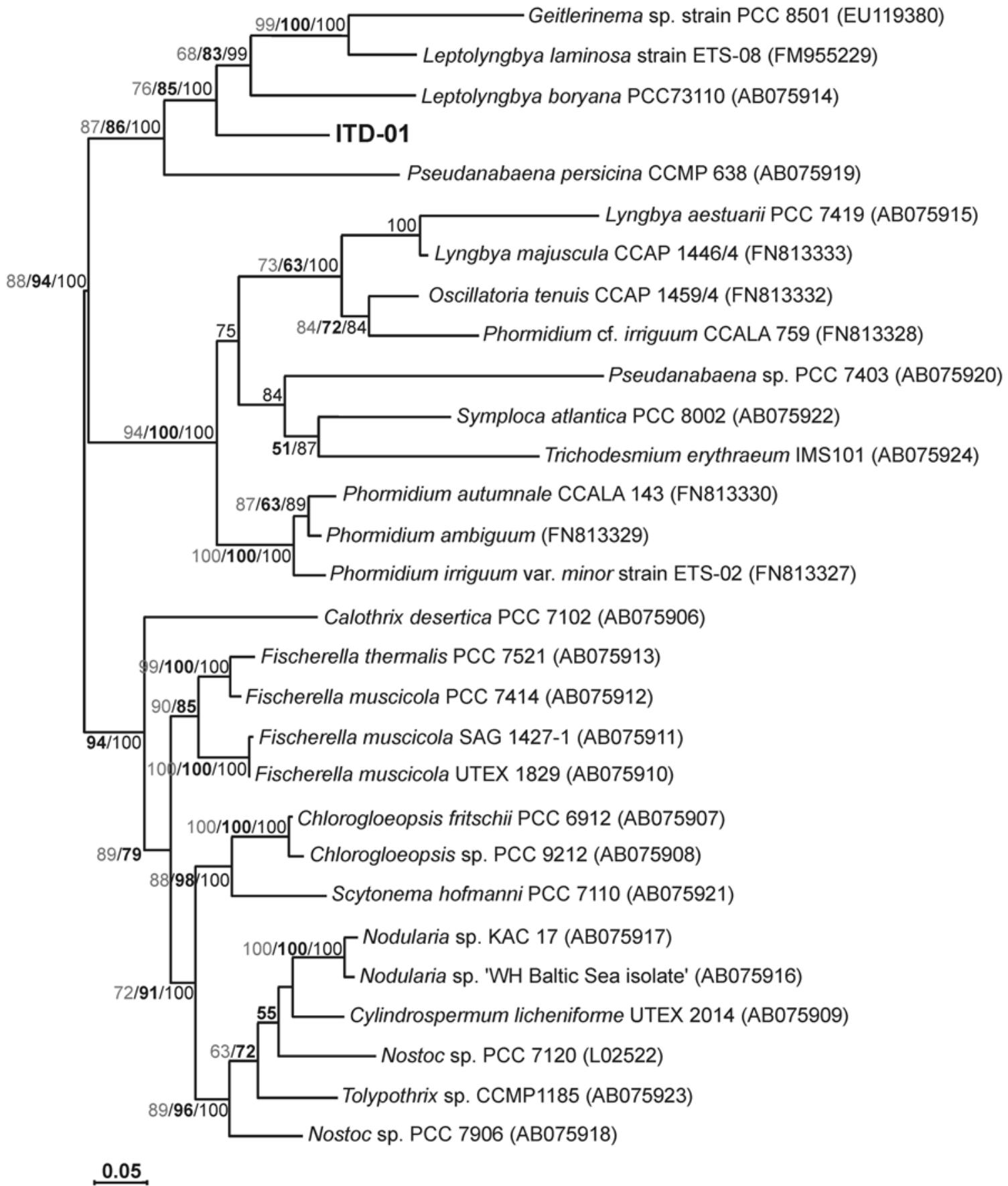

Fig. 6. Phylogenetic tree based on the $r b c \mathrm{~L}$ gene sequences, reconstructed using the maximum-likelihood analysis. MP and ML bootstrap values ( $\geq 50 \%$ ) and Bayesian posterior probabilities are provided for each node (MP in grey, ML in bold, and BI in normal font). GenBank accession numbers are indicated in bracket. Bar represents 0.05 nucleotide substitutions per site.

clustered different Leptolyngbya strains, most of which identified at the species level: L. boryana, $L$. foveolarum, $L$. tenerrima and $L$. angustata (99/100/100\%BT/BT/PP).Inparticular,L. boryana is the type-species of the genus Leptolyngbya (KomÁrek \& ANAgnostidis 2005). Clade A (81/100/100\% BT/BT/PP) and clade E (98/100\% $\mathrm{BT} / \mathrm{PP}$ ), each one with evident subclusters inside, are formed by other cyanobacteria attributed to the Leptolyngbya genus, thus furtherly confirming the heterogeneity and polyphyly of this group as it is currently intended. Finally, clade D (95/83/85\% BT/BT/PP) and clade F (52/98/100\% BT/BT/PP) included different cyanobacteria attributed to the genus Pseudanabaena.

Clades A, B, C, D, E, and F together represented the Pseudanabenaceae family, which resulted sister taxon to clade $\mathrm{G}$ in the phylogenetic 
tree, with a 100/100\% BT/PP support. Clade $\mathrm{G}(73 / 90 \% \mathrm{BT} / \mathrm{PP})$ included members of the Phormidiaceae and Oscillatoriaceae families.

Thus, also from the 16S rDNA phylogenetic reconstruction, strain ITD-01 results belonging to the order Oscillatoriales, family Pseudanabaenaceae, and to the current genus Leptolyngbya. However our analyses confirm that several distinct clades hide under the name Leptolyngbya and strain ITD-01 places outside clade C, which represents the actual Leptolyngbya species. Therefore, for its position in the 16S rDNA tree topology, its morphology corresponding to the description made for the subgenus Protolyngbya, and in absence of other public available sequences for the members of this subgenus, we think that ITD-01 can be the first sequenced strain of the current subgenus Protolyngbya. Moreover, our phylogenetic analyses, as well as its different morphological features, lead us to propose that this subgenus should become a genus separate from Leptolyngbya, as already suggested by KOMÁREK (2010, personal communication). This is confirmed by the identity percentages (88.6-89.2\%) between ITD-01 16S rDNA gene sequences and those of clade $\mathrm{C}$ members, which are below the proposed threshold value in order to ascribe two cyanobacteria to the same genus (STACKebrandt \& Goebel 1994).

Although based on a limited number of sequences, the $r b c \mathrm{~L}$ gene phylogenetic reconstruction (Fig. 6) confirmed the belonging of strain ITD-01 to the order Oscillatoriales and Pseudanabaenaceae family $(87 / 86 / 100 \%$ BT/ $\mathrm{BT} / \mathrm{PP})$, but, also in this case, it resulted clearly distinct from L. boryana.

In the light of our survey, we suggest that strain ITD-01 might represent the first described entity belonging to a new cyanobacterial genus, whose name might be Protolyngbya. However, in order to define a new genus further investigations should be carried out in the future, through the isolation and polyphasic characterization of other thin filamentous cyanobacteria belonging to this new taxon.

\section{Acknowledgements}

This work was supported by grants provided by by Centro Studi Termali Isola d'Ischia "Julio Jasolino" (Ischia Naples, Italy), by Associazione Termalisti Isola d'Ischia (Ischia, Naples, Italy) and by Centro Studi Termali "Pietro d'Abano", Abano Terme (Padova, Italy). The authors wish to thank Dr. Nello Carraturo (Resp. U.O.P.C. Ischia-ASL Napoli2 Nord) for his suggestions in the choice of sampling sites and collaboration.

\section{References}

Abed, R.M.M, Garcia-Pichel, F. \& HernándezMARINÉ, M. (2002): Polyphasic characterization of benthic, moderately thermophilic cyanobacteria with very thin trichomes and the proposal of Halomicronema excentricum gen. nov., sp. nov. - Arch. Microbiol. 177: 361-370.

Albertano, P. \& KováččK, L. (1994): Is the genus Leptolyngbya (Cyanophyte) a homogeneous taxon?-Algological Studies 75: 37-51.

Altschul, S.F., Gish, W., Miller, W., Myers, E.W. \& LipMAN, D.J. (1990): Basic local alignment search tool. - J. Mol. Biol. 215: 403-410.

Bennett, A. \& Bogorad, L. (1973): Complementary chromatic adaptation in a filamentous bluegreen alga. - J. Cell Biol. 58: 419-435.

Bhat, V.B. \& Madyastha, K.M. (2001): Scavenging of peroxynitrite by phycocyanin and phycocyanobilin from Spirulina platensis: protection against oxidative damage to DNA. Biochem. Bioph. Res. Comm. 285: 262-266.

Bruno, L., Billi, D., Bellezza, S. \& Albertano, P. (2009): Cytomorphological and Genetic Characterization of Trogophilic Leptolyngbya Strains Isolated from Roman Hypogea. - Appl. Environ. Microbiol.75: 608-617.

Bruno, A., Rossi, C., Marcolongo, G., Di Lena, A., Venzo, A., Berrie, C.P. \& Corda, D. (2005): Selective in vivo anti-inflammatory action of the galactolipid monogalactosyldiacylglycerol. - Eur. J. Pharmacol. 524: 159-168.

Casamatta, D.A., Johansen, J.R., Vis, M.L. \& BRoAdwATER, S.T. (2005): Molecular and morphological characterization of ten polar and near-polar strains within the Oscillatoriales (Cyanobacteria). - J. Phycol. 41: 421-438.

Eriksen, N.T. (2008): Production of phycocyanin - a pigment with applications in biology, biotechnology, foods and medicine. - Appl. Microbiol. Biotechnol. 1: 1-14.

Felsenstein, J. (2003): Inferring phylogenies. Sinauer Associates, Sunderland, Massachusetts.

Gerwick, W.H., Coates, R.C., Engene, N., Gerwick, L., Grindberg, R.V., Jones, A.C. \& Sorrels, C.M. (2008): Giant Marine Cyanobacteria produce exciting potential pharmaceuticals. - Microbe 3: $277-284$.

Guindon, S. \& Gascuel, O. (2003): A simple, fast, and accurate algorithm to estimate large phylogenies by maximum likelihood. - Syst. Biol. 52: 696704.

Ishida, T., YoкотA, A. \& Sugiyama, J. (1997): Phylogenetic relationships of filamentous 
cyanobacterial taxa inferred from $16 \mathrm{~S}$ rRNA sequence divergence. - J. Gen. Appl. Microbiol. 43: 237-241.

Jungblut, A., Hawes, I., Mountfort, D., Hitzfeld, B., Dietrich, D.R., Burns, B.P. \& Neilan, B.A. (2005): Diversity within cyanobacterial mat communities in variable salinity meltwater ponds of McMurdo Ice Shelf, Antarctica. Environ. Microbiol. 7: 519-529.

KomÁreK, J. (2005): The modern classification of Cyanoprokaryotes (Cyanobacteria). - Ocean. Hydrob. Studies 34: 5-17.

KomÁreK, J. (2007): Phenotype diversity of the cyanobacterial genus Leptolyngbya in the maritime Antarctic. - Pol. Polar Res. 28: 211231.

KomÁreK, I. \& AnAgnostidis, K. (2005): Cyanoprokaryota 2. Teil: Oscillatoriales. In: Büdel, B., GÄrtner, G., Krienitz, L. \& SCHAGERL, M. (eds): Süsswasserflora von Mitteleuropa Band 19/2. - 759 pp., Elsevier $\mathrm{GmbH}$, Spektrum Akademischer Verlag, Heidelberg.

KomÁREK, J. \& Č́́SLAVSKÁ, J. (1991): Thylakoid patterns in oscillatorialean cyanophytes. -Algological Studies 64: 267-270.

KomÁrek, J., Kopecky, J. \& CepÁK, V. (1999): Generic characters of the simplest cyanoprokaryotes Cyanobium, Cyanobacterium and Synechococcus. - Cryptogam. Algol. 20: 209222.

Lalli, A., Andreoli, C., Ceschi-Berrini, C., De Appolonia, F. \& Marcolongo, G. (2004): Antiinflammatory active principles in Euganean thermal MUD. - European patent 05100038.8.

Lanave, C., Preparata, G., Saccone, C. \& Serio, G. (1984): A new method for calculating evolutionary substitution rates. - J. Mol. Evol. 20: 86-93.

López-Cortés, A., García-Pichel, F., Nübel, U. \& VÀZQUEZ-JuÀREZ, R. (2001): Cyanobacterial diversity in extreme environments in Baja California, Mexico: a polyphasic study. - Int. Microbiol. 4: 227-236.

Ludwig, W., Strunk, O., Westram, R., Richter, L., Meier, H., Yadhukumar, Buchner, A., Lai, T., Steppi, S., Jobb, G., Förster, W., Brettske, I., Gerber, S., Ginhart, A.W., Gross, O., Grumann, S., Hermann, S., Jost, R., König, A., Liss, T., Lüssmann, R., May, M., Nonhoff, B., Reichel, B., Strehlow, R., Stamatakis, A., Stuckmann, N., Vilbig, A., Lenke, M., Ludwig, T., Bode, A. \& SChleifer, K-H. (2004): ARB: a software environment for sequence data. - Nucleic Acids Res. 32: 1363-1371.

Maddison, W.P. \& Maddison, D.R. (2009): Mesquite: a modular system for evolutionary analysis. Version 2.71. http://mesquiteproject.org.
Marcolongo, G., De Appolonia, F., Venzo, A., Berrie, C.P., Carofiglio, T. \& Ceschi-Berrini, C. (2006): Diacylglycerolipids isolated from a thermophile cyanobacterium from the Euganean hot springs. - Nat. Prod. Res. 20: 766-774.

Moro, I., Rascio, N., La Rocca, N., Di Bella, M. \& AndReoli, C. (2007): Cyanobacterium aponinum, a new Cyanoprokaryote from the microbial mat of Euganean thermal springs (Padua, Italy). - Algological Studies 123: $1-15$.

Moro, I., Rascio, N., La Rocca, N., Sciuto, K., Albertano, P., Bruno, L. \& Andreoli, C. (2010): Polyphasic characterization of a thermo-tolerant filamentous cyanobacterium isolated from the Euganean thermal muds (Padova, Italy). - Eur. J. Phycol. 45: 143-154.

Paerl, H.W., Pinckney, J.L. \& Steppe, T.F. (2000): Cyanobacterial-bacterial mat consortia: examining the functional unit of microbial survival and growth in extreme environments. - Environ. Microbiol. 2: 11-26.

Palińska, K.A. \& Marquardt, J. (2008): Genotypic and phenotypic analysis of strains assigned to the widespread cyanobacterial morphospecies Phormidium autumnale (Oscillatoriales). Arch. Microbiol. 189: 325-335.

Perrière, G. \& Gouy, M. (1996): WWW-Query: An on-line retrieval system for biological sequence banks. - Biochimie 78: 364-369.

Pitschmann, H. (1969): Beiträge zur Thermalalgenflora der Insel Ischia. - Ber. nat.-med. Verein Innsbruck 57: 185-193.

Rippka, R., Deruelles, J., Waterbury, J.B., Herdman, M. \& Stanier, R.Y. (1979): Generic Assignments, Strain Histories and Properties of Pure Cultures of Cyanobacteria. - J. Gen. Microbiol. 111: 1-61.

Romay, C., Armesto, J., Remirez, D., Gonzalez, R., Ledon, N. \& Garcia, I. (1998): Antioxidant and anti-inflammatory properties of C-phycocyanin from blue-green algae. - Inflamm. Res. 47: 36-41.

Ronquist, F. \& Huelsenbeck, J.P. (2003): MrBayes 3: Bayesian phylogenetic inference under mixed models. - Bioinformatics 19: 1572-1574.

Sánchez-Baracaldo, P., Hayes, P.K. \& Blank, C.E. (2005): Morphological and habitat evolution in the Cyanobacteria using a compartmentalization approach. - Geobiology 3: 145-165.

Singh, S., Kate, B.N. \& BanerJee, U.C. (2005): Bioactive Compounds from Cyanobacteria and Microalgae: An Overview. - Crit. Rev. Biotechnol. 25: 73-95.

Sivonen, K. \& BöRner, T. (2008): Bioactive compounds produced by cyanobacteria. - In: Herraro, A. \& FLores, E. (eds): The cyanobacteria: Molecular Biology, Genomics and Evolution. - pp. 159- 
197, Caister Academic Press, Norfolk.

Stackebrandt, E. \& Goebel, B.M. (1994): Taxonomic note: a place for DNA-DNA reassociation and $16 \mathrm{~S}$ rRNA sequence analysis in the present species definition in bacteriology. - Int. J. Syst. Bacteriol. 44: 846-849.

TAKaichi, S. \& Mochimaru, M. (2007): Carotenoids and carotenogenesis in cyanobacteria: unique ketocarotenoids and carotenoid glycosides. Cell. Mol. Life Sci. 64: 2607-2619.

Tamura, K., Dudley, J., Nei, M. \& Kumar, S. (2007): MEGA4: Molecular Evolutionary Genetics Analysis (MEGA) software version 4.0. - Mol. Biol. Evol. 24: 1596-1599.

Taton, A., Grubisic, S., Brambilla, E., De Witt, R. \& Wilmotte, A. (2003): Cyanobacterial diversity in natural and artificial microbial mats of lake Fryxell (McMurdo Dry Valleys, Antarctica): a morphological and molecular approach. - Appl. Envir. Microbiol. 69: 5157-5169.

Taton, A., Grubisic, S., Balthasart, P., Hodgson, D.A., Laybourn-Parry, J. \& Wilmotte, A. (2006a): Biogeographical distribution and ecological ranges of benthic cyanobacteria in East Antarctic lakes. - FEMS Microbiol. Ecol. 20: $1-18$.

Taton, A., Grubisic, S., Ertz, D., Hodgson, D.A., Piccardi, R., Biondi, N., Tredici, M.R., Mainini, M., Losi, D., Marinelli, F. \& Wilmotte, A. (2006b): Polyphasic study of Antarctic cyanobacterial strains. - J. Phycol. 42: 12571270.

Thompson, J.D., Higgins, D.G. \& Gibson, T.J. (1994): Clustal W: improving the sensitivity of progressive weighting position-specific gap penalties and weight matrix choice. - Nucleic Acid Res. 22: 4673-4680.

Tomitani, A., Knoll, A.H., Cavanaugh, C.M. \& Ohno, T. (2006): The evolutionary diversification of cyanobacteria: molecular-phylogenetic and paleontological perspectives. - Proc. Natl. Acad. Sci. USA 103: 5442-5447.

Vadiraja, B.B., Gaikwad, N.W. \& Madyastha, K.M. (1998): Hepatoprotective effect of C-phycocyanin: Protection for carbon tetrachloride and $\mathrm{R}-(+)-$ pulegnone-mediated hepatotoxicity in rats. - Biochem. Biophys. Res. Commun. 249: 428-431.

Wacklin, P., Hoffmann, L. \& Komárek, J. (2009): Nomenclatural validation of the genetically revised cyanobacterial genus Dolichospermum (RALFs ex Bornet et Flahault) comb. nova. Fottea 9: 59-64.

Ward, D.M., Ferris, M., Nold, S. \& Bateson, M. (1998): A natural view of microbial biodiversity within hot spring cyanobacterial mat communities. Microbiol. Mol. Biol. Rev. 62: 1353-1370.

\section{Web sources}

http://www.terme.ischia.it/uk/

http://www.ischiaonline.it/

http://www.ncbi.nlm.nih.gov/blast

(C) Czech Phycological Society (2011)

Recieved Sept 2010

Accepted Dec 2010 